\title{
14. The rise and fall of the magic kingdom: understanding Kevin Rudd's domestic statecraft
}

\author{
MARK EVANS
}

There is nothing more difficult to take in hand, more perilous to conduct, or more uncertain in its success, than to take the lead in the introduction of a new order of things. (Niccolo Machiavelli, The Prince, Chapter 6, para 5)

Clearly politics has its own momentum but you have to keep one eye on the rear-vision mirror. That's where the lessons of history are to be found and by any measure the election of 2007 was political history. (Jones 2008:ix)

If 2007 was considered a progressive landmark in Australian political history, 2010 would prove to be one of its low points. The collapse in the support for the Australian Labor Party (ALP) at the August election demonstrated the damage the party has done to itself in the eyes of many voters by allowing factional ambition to undermine representative and responsible government and to determine that the firing of prime ministers should rest with the party rather than the public.

Most assessments of Kevin Rudd's demise as the twenty-sixth Prime Minister of Australia after two years and 204 days in power have tended to focus on the role of his 'troublesome' personality in undermining his power base and ultimately his legacy. He has variously been accused of being 'a man of words, but little else' (Nethercote 2010), governing 'as a state premier' (Crabb 2010), of being 'a fraudulent facsimile of the real thing' (Penberthy 2009), a 'control freak' (Kelly 2010), and being 'a politician with rage at his core' (Marr 2010a:4). This last characterisation was expressed in David Marr's essay 'Power Trip: The political journey of Kevin Rudd', when he also observed:

Leaders aren't there to be liked. Being an arsehole is no bar to high office. They always disappoint. The public understands this. And people know the climb to power can be bloody. Such things are forgiven if it all proves worthwhile. But of Rudd it has to be said that there is a large number of people who, having worked with him as a diplomat, public servant, shadow minister, leader of the opposition or lately as prime minister, loathe the man. Between the verdicts of the public and those who come to know him face to face, there is a curiously wide gulf... [There is a] fundamental question about Rudd that remains unanswered: who is he? 
This essay could well represent the tipping point in Rudd's political fortunes as it gave rise to concerted internal party opposition to his leadership. Marr's devastating critique concludes that 'Kevin Rudd remains hidden in full view'. In evaluating the making of Kevin Rudd as a force in Australian politics back in 2007, Simon Mann was asked to reflect on his operating style in the inner sanctum of the reformist government under the then Queensland Labor Premier, Wayne Goss, and came up with a similar conclusion to Marr's:

Methodical, process-driven and naturally conservative, Rudd was to many people the proverbial man on a mission. Many found his style abrasive and uncompromising, and Goss himself has conceded that Rudd was at times during those torrid years in Queensland a bit of a bastard, 'because sometimes you have to be if you want to make a difference'. (Mann 2008:14)

While there can be no doubt that personality is an important resource of prime ministerial power and, by implication, is a liability if it is absent, it needs to be understood within the broader set of powers and constraints that operate in and on the core executive in the 'OzMinster' system.'OzMinster' is a term used by Ken Matthews AO, retiring Chief Executive of the National Water Commission, in his valedictory address, 6 October 2010, at Old Parliament House. He went on to argue: 'In my view we should be proud of our uniquely Australian model of public administration. For me the fact that it has evolved so far from its Westminster origins is thoroughly positive.' This chapter offers a simple corrective in this regard. It argues that our traditional understanding of prime ministerial power as exercised through cabinet government tends to oversimplify relationships within complex decisionmaking centres. Indeed, the Rudd debacle clearly demonstrates that sustainable prime ministerial power rests on the incumbent's recognition that their powerbase is determined by a broad set of resource dependencies. Resource dependence theory in this context refers to those resources that a prime minister needs to govern effectively and legitimately. In combination, they provide the key source of prime ministerial power or impotence which in the Australian context includes at least four dimensions: the core executive territory, media relations, the citizenry and the Prime Minister's party itself. In short, as soon as Rudd lost sight of the importance of these resource dependencies, he started to lose his grip on power.

This argument is developed in two parts. Part one begins by situating the study within the context of debates about prime ministerial power. It highlights the importance of understanding power relations in the core executive territory as the product of the interactive relationship between structure (social, institutional and political) and agency (politics) and argues that resource dependency provides the critical variable for understanding this relationship. It then identifies the ingredients of effective and, by implication, ineffective statecraft in order to understand the fall of Kevin Rudd. Part two then applies this framework to the Rudd administration. The constraints of space make it impossible to examine each 
dimension of statecraft with the detail of scrutiny and analysis that it deserves. What follows is therefore an intentionally simple, selective and critical guide to the Rudd government.

\section{On statecraft and resource dependency}

What is statecraft? The crude answer is that it is the art of winning elections and achieving some necessary degree of governing competence in office. (Bulpitt 1986a:19-39)

Traditionally, the study of prime ministerial power has centred on the prime ministerial government (Crossman 1963; Hennessy 1986, 2000) versus the cabinet government theses (Rhodes et al. 2009:83). The prime ministerial government thesis views executive government as the exertion of the Prime Minister's powers or what has also been referred to as 'monocratic government'. On what empirical basis is this claim justified? Usually, reference is made to the Prime Minister's significant powers of patronage and his/her capacity to shape the political complexion of government and set the policy agenda; access to superior knowledge resources; the ability to shape the Public Service; political visibility; and party leadership. Paul Keating, for example, has often been cited as the personification of this style of government: 'a domineering prime minister with little interest in the process of government' (Rhodes et al. 2009:83).

Conversely, the cabinet government thesis focuses on the two key powers of the Prime Minister - patronage and his/her control of the agenda-and argues that these powers are severely constrained. In Australia, prime ministerial dominance has been a key feature of executive government since World War I (Weller 2007). Crucially, however, the key source of their powers emanates from cabinet itself. As Rhodes et al. (2009:82-3) observe in their magisterial comparison of executive government in Westminster-style democracies, '[f]ew would deny that a centralisation of government occurred under John Howard...Howard was a traditionalist who did not bypass cabinet or the regular "party room" meetings... [but h]is prime ministerial dominance was based on cabinet'.

As Kelly (2005:3) notes, 'good prime ministers must be good team leaders', and he cites Malcolm Fraser (1975-83), Bob Hawke (1983-91) and John Howard (19962007) as the exemplars in this regard. Weller $(1992: 5,27)$ observes that 'executive government is collective in its form and its expectations' and 'the development of cabinet government to a higher level of activity and authority has... been a crucial factor in extending the prime minister's authority and span of control'. Thus, Rhodes et al. (2009:83) conclude that 'despite different styles of leadership, Australia continues to produce cabinet government under its various prime ministers'. 
There are four key problems with this debate: it is irresolvable (every example of monocratic government can be trumped with an example of cabinet government); it assumes power is a zero-sum game that either the Prime Minister or the cabinet possesses; it simplifies relationships within complex decision-making centres and suggests that the Prime Minister has the capacity to govern solely through the Department of the Prime Minister and Cabinet (PM\&C); it ignores broader institutional, political and economic factors including federalism; and it overemphasises issues of personality. So, is there an alternative framework of analysis?

The more compelling work on the core executive focuses on different conceptions of dependency. David Marr's (2010a) account of the Rudd government, for example, develops a form of prime ministerial clique thesis focusing on policy making by cabal or an 'inner' or 'kitchen' cabinet of Kevin Rudd, Julia Gillard, Wayne Swan and Lindsay Tanner. An alternative would be to apply a segmented decision model of executive government (Rose 2001). This approach recognises that the Prime Minister and members of cabinet operate in different policy arenas. Ministers operate below interdepartmental level, while the Prime Minister operates primarily in the areas of strategic development, defence, foreign affairs, and the economy. Hence, power-dependency relationships exist between the Prime Minister and his colleagues in these areas and across the other portfolios of government. This approach stresses the complex nature of contemporary decision making in the core executive, arguing that it is simply not possible for a prime minister to adopt a presidential-style of leadership and stay on top of the job. Or at least, they would do so at their peril!

Martin Smith's (1994) alternative model of prime ministerial power follows a similar cue and formulates a dependency thesis following Rhodes (1995) and Dunleavy and Rhodes (1990) that centres on the contingent power of the Prime Minister. Smith contends that prime ministerial/cabinet relations operate within an institutional and political context underpinned by resource dependencies (see Figure 14.1). By implication, the relative powers of prime minister and cabinet are contingent on the institutional and political context. In certain periods, prime ministers will enjoy enhanced autonomy (in the aftermath of a successful election campaign, for instance) and might even exhibit presidential characteristics; however, their long-term survival rests on the development of strong working relationships with their ministerial colleagues, the Public Service and their party. Smith's characterisation of executive government recognises the importance of resource dependency to the art of governing, or what Jim Bulpitt (1986a, 1986b) has termed 'statecraft'. Now this is an important argumentative turn in this chapter. Smith's analysis takes us only so far in developing a model of prime ministerial power. We also require an insight into the ingredients of effective and, by implication, ineffective statecraft in order to understand the fall of Kevin Rudd, and the concept of resource dependency provides only part of the answer. 
So what does statecraft involve? The approach was originally developed by the British political scientist Jim Bulpitt in 1986 and has subsequently been applied by others (see Buller 2000). It emerged in response to a number of authors who stressed the importance of the 'new right' ideological project as an understanding of the emergence and development of Thatcherism in the United Kingdom (see Hall and Jacques 1983). Bulpitt disagreed with writers such as Hall and Jacques that the new-right project provided the grand design of the Thatcher project and shaped the nature of the policy agenda. He argued that ideas themselves were never that important. Instead, he emphasised the importance of what he termed statecraft or the 'politics of governing'.

\begin{tabular}{|c|c|c|}
\hline & $\begin{array}{l}\text { Environmental factors } \\
\text { World events } \\
\text { Economic conditions } \\
\text { Policy success/failure } \\
\text { Level of popular support } \\
\text { Level of parliamentary, senate } \\
\text { and state support }\end{array}$ & \\
\hline $\begin{array}{l}\text { Prime ministerial } \\
\text { resources } \\
\text { Patronage } \\
\text { Department of the Prime } \\
\text { Minister and Cabinet } \\
\text { Council of Australian } \\
\text { Governments (COAG) } \\
\text { Authority } \\
\text { Finance } \\
\text { Party } \\
\text { Media }\end{array}$ & & $\begin{array}{l}\text { Ministerial } \\
\text { resources } \\
\text { Authority/political } \\
\text { support } \\
\text { Department/ } \\
\text { bureaucracy } \\
\text { Knowledge/time } \\
\text { Policy networks } \\
\text { Policy success }\end{array}$ \\
\hline $\begin{array}{l}\text { Means of mobilisation } \\
\text { Monocratic } \\
\text { Collectivist } \\
\text { Interventionist } \\
\text { Coordinator }\end{array}$ & & $\begin{array}{l}\text { Means of } \\
\text { mobilisation } \\
\text { Coalition } \\
\text { Tactical } \\
\text { Threat } \\
\text { Offer }\end{array}$ \\
\hline \multicolumn{3}{|c|}{$\begin{array}{l}\text { Statecraft-the art of winning elections and achieving governing competence } \\
\text { Achievement of: } \\
\text { Governing objectives } \\
\text { Stable governing code } \\
\text { Political argument hegemony } \\
\text { Party management }\end{array}$} \\
\hline
\end{tabular}

\section{Figure 14.1 A resource-dependency model of prime ministerial power}

Note: This is an interactive model in the sense that these sets of variables do not exist in a vacuum; they interact in complex and often unexpected ways.

Source: Developed from Smith (1994) and Bulpitt (1986a). 
Statecraft crystallises around the study of a core political elite, which Bulpitt (1986a, 1986b, 1995) refers to as 'the centre' or 'the court', composed of party leaders and senior public servants and policy advisers. He argues that this group has its own interests, which are distinct from the rest of society's, and they can often successfully pursue these interests, even in the face of opposition from other actors. In other words, the statecraft approach represents an elite theory of public policy making.

According to Bulpitt, there are three conditions of successful statecraft (see Figure 14.2). First, the centre/court needs to establish a set of governing objectives with the aim of winning elections and retaining office by achieving an image of governing competence. Second, in order to achieve these objectives, it has to develop a governing code - a set of principles, beliefs and practices. This involves the preservation and promotion of domestic autonomy over what Bulpitt calls 'high politics', and the devolution of delivery responsibility to 'low politics'. In practical terms, high politics refers to all those policy issues that the centre considers to be vital to its chances of winning elections and achieving an image of governing competence, so that autonomy over high politics is crucial to the achievement of governing competence. Low politics is a residual category. It refers to all the other matters perceived by the centre to be too mundane, difficult or time consuming to handle. Third, in trying to win elections and achieve some semblance of governing competence, the centre/ court will employ a set of 'political support mechanisms' to assist the governing code. These mechanisms refer to the functions of party management and the achievement of political argument hegemony. As Bulpitt (1986a:22) puts it, this refers to 'a winning rhetoric in a variety of locations, winning because either the framework of the party's arguments becomes generally acceptable, or because its solutions to a particularly important political problem seem more plausible than its opponents".

In short, then, statecraft is about the politics of governing. It involves short-term tactical manoeuvring - qualities that are essential to every successful electoral strategy. It is also concerned with longer-term strategic calculation and action. For Bulpitt, governments can think strategically and alter institutions and structures to help them achieve their political goals more easily. The most highprofile illustrations of the application of the statecraft approach in a Westminsterstyle democracy can be found under Margaret Thatcher in the United Kingdom (1979-90) and the long period of Coalition rule under John Howard in Australia (1996-2007).Bulpitt applied this theory to British 'historical politics' across the twentieth century, identifying three statecraft regimes (1922-61, 1960s-78 and 1979-91) and sets of governing codes and political support mechanisms that delivered successful statecraft (see Bulpitt 1986a, 1986b, 1995). Both projects achieved dominance in high politics, combined with a necessary degree of 
governing competence thereby ensuring electoral dominance. Both projects were driven largely by pragmatism - owing more to the need to maintain electoral success than to appeal to a particular ideology. Although the statecraft approach remains theoretically underdeveloped, it does provide the contours for an elite theory of domestic statecraft that emphasises the role of the party political elite in forwarding a strategy for winning the war of political ideas and maintaining electoral success. A comprehensive theory would, however, involve a detailed operational exposition of the concepts of political argument hegemony, governing competence, polity management and strategy. Moreover, it can be argued that the statecraft characterisation has particular traction in an 'OzMinster' system where there is a three-year electoral cycle, the window of opportunity for policy change is rarely open for more than two years at a time and the next election campaign is always on the horizon.

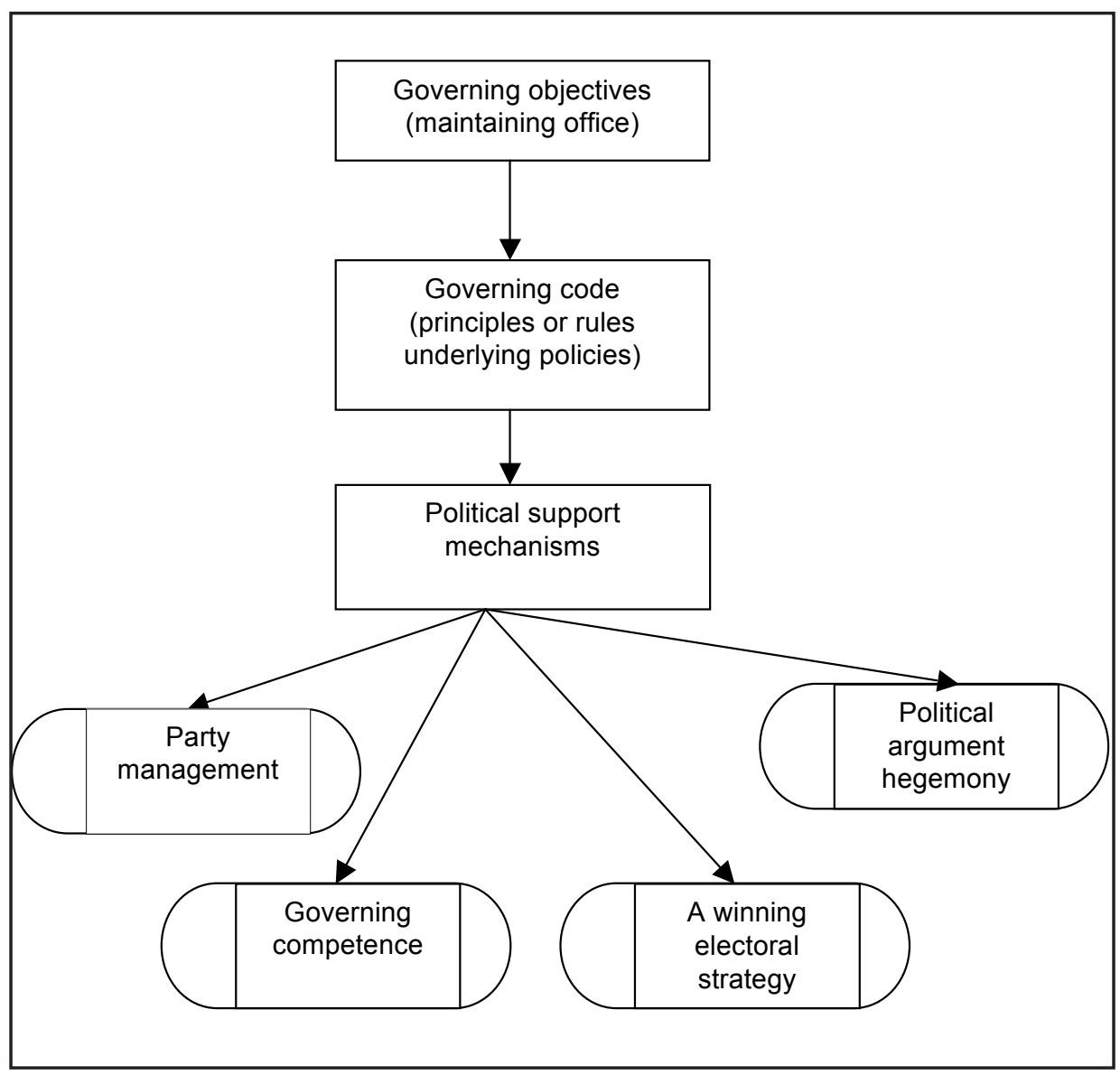

Figure 14.2 The statecraft approach 
The following evaluation of Kevin Rudd's domestic statecraft will be organised around the four key dimensions of the statecraft approach: the achievement of governing objectives; the establishment of a stable governing code; political argument hegemony; and party management. It is argued that these dimensions of prime ministerial power are sustainable in contemporary government only if underpinned by the concept of resource dependency.

\section{Kevin07: Rudd ascendant－governing objectives}

We're here to serve the government of the day regardless of its politics; but we couldn't help feeling excited at the prospects of a Rudd government after such a long period of Howard rule. (Author interview with former senior public servant)

Successful statecraft requires the achievement of governing objectives: the ability to win and maintain power through demonstrating governing competence. In his resignation speech, Rudd summarised his perception of the government's major achievements (see Box 14.1). The list is notable for the number of early successes and in terms of the large-scale reforms for delivery failure. Moreover, certain of these early wins would later suffer severe setbacks. The early successes included: signing the Kyoto Protocol to limit greenhouse gas emissions (3 December 2007); the welcome to country from local Aboriginal people at the opening of Australia's forty-second Parliament (13 February 2008); a parliamentary apology led by the Prime Minister for the effect of past government policies on Indigenous people (14 February 2008). In his resignation speech, he stated that he was 'most proud' of this achievement, noting that 'the apology was unfinished business for our nation. It is the beginning of new business for our nation.' Nonetheless, in the main, these policies symbolised a clear break with the Howard years, as Judith Brett (2008:6) puts it, 'from age to youth, from fear to hope, from private to public'. They also provided a strong early signal that this was a prime minister intent on achieving governing objectives. At the same time, it should be noted that of the 23 'achievements' listed in Box 14.1, only 12 were actually completed at the time of the speech. The remainder were works in progress, or, at worst, announcements of future endeavours.

What is also significant about the list is the number of activities in the area of economic management. As George Megalogenis (2008:47) has put it, however, 'economic management is of course the oxymoron of modern politics. The notion that federal governments manage the economy in the same way that a chief executive would run a business is, frankly, delusional.' Nevertheless, creating the image of sound economic management remains, for the most part, the key ingredient of electoral success. Indeed, the 2010 election result would undermine the old shibboleth for understanding voting behaviour- 'it's the economy, 
stupid!' - clearly illustrating that these have been exceptional times. The Rudd government does deserve credit for avoiding recession, which allowed Rudd and Swan to engender the rhetoric of sound economic management at every available opportunity: 'we've set a new benchmark for responsible economic management... better than any other major advanced economy' (McLennan and Cronin 2010:4). In sum, favourable economic circumstances harnessed through prompt economic management provided the Rudd government with the best possible conditions for affecting successful statecraft.

\section{A stable governing code}

Before too long it became evident that the only time we were able to really move things on was when the Prime Minister was out of the country and Julia was in charge. (Former senior public servant, Interview with author)

Successful statecraft, in the main, requires the establishment of a stable governing code throughout the core executive - clear and consistent messages - which can be easily transferred into policy and provide the court with a source of cohesiveness and purpose. It should also provide the essential glue for resource dependency to work as the first principle of governing. The Rudd government fell short of the mark in three main respects in this regard: its failure to govern through cabinet; its inability to develop a strong working relationship with the Public Service at the heart of the core executive; and the absence of a coherent governing code or reform agenda.

First, Rudd failed to empower his cabinet to implement the governing code. As David Marr reflects:

Well as I understand it, Cabinet doesn't really work any longer...there are Cabinet meetings, but Cabinet is for the most part presented with the decisions that have been taken by what's now commonly called the 'Gang of Four', which is Rudd, Gillard, Swan and Tanner...It has become more and more concentrated power and the administration of the country, more and more concentrated in Rudd's own hands and in the hands of people very close to him. (Marr 2010b:1)

As Trinca et al. (2010:2) observed in the aftermath of Rudd's fall, a senior bureaucrat informed them that 'Rudd was so determined to handle everything himself that his office became a giant black hole'. He was accused of 'failing to move the paper', of asking staff to engage in resource-intensive work 'with no apparent purpose', of treating staff 'as if diseased'. In his own words, the Prime Minister failed to affect 'a new paradigm in Australian governance'. Indeed, the use of the very un-Australian word 'paradigm' would become a metaphor for the failure of his style of leadership within the senior echelons of the Public Service. 
We kept Australia out of recession. Had we not, half a million people would have been out of work.

We got rid of WorkChoices and restored decency to the work place.

We started to build the nation's infrastructure including the National Broadband Network, which will transform the economy in ways we have yet to conceive.

We began the education revolution-300,000 extra computers in classrooms.

We now have trade centres built to service every one of the nation's secondary schools.

New school libraries are springing up across the country, often in schools that have never had one.

We now have nationwide early childhood education.

We now have a national curriculum.

We now have 50,000 more university places and have invested so much more in our universities, in our research.

We have reformed the health system; a national health and hospitals network... [the new funding arrangements will be seen as a] very, very deep reform.

We are building 20 regional cancer centres right across our country.

We now have a National Organ Transplant Authority.

We have restored decency to the aged pension. The $\$ 100$ extra is the biggest increase ever.

We now have paid parental leave.

We are on track to halve homelessness in the country.

We are adding 20,000 additional units of social housing.

We signed the Kyoto Protocol.

We boosted the renewable energy target to 20 per cent. 
We tried three times to get an emissions trading system through parliament.

We now have a Murray Basin Authority and for the first time in our history have a basin-wide plan and a basin-wide cap on water.

On the global stage Australia is now at the table of the G20. We lobbied hard and long for that. It is a good achievement for Australia for the future.

We are closing the gap between indigenous and non-indigenous Australians.

We greeted the Stolen Generations.

Source: The Australian, 24 June 2010, <http://www.theaustralian.com.au/full-transcript-of-kevin-ruddsfarewell-speech/story-fn5vfgwx-122588379657l>

Second, Rudd's ill-conceived decision in May 2008 to declare war on the Public Service in response to a cabinet leak exposed to public view what had hitherto been the subject only of Canberra gossip: the Prime Minister's limited interpersonal skills (see, for example, ABC 2008; Fraser and Hannon 2008; Lewis and Rehn 2008; McDonnell 2008). Rudd attacked the Public Service for its lack of work ethic, demanding a '24/7' commitment and stating that 'the public demands it!'. During the episode, Rudd noted that one of his staff had commented recently that one year with him was akin to a 'dog year' - equal to seven 'human years'. The fact that Rudd viewed this to be a compliment is cause for concern. It is unsurprising therefore that the Department of the Prime Minister and Cabinet (PM\&C) had a 53 per cent turnover in staff in less than a year, leading one policy advisor to note that 'PM\&C was once the place to be; now it's the place not to be' (Former senior public servant, Interview with author). For Rudd, 'it was a storm in a teacup', but for many senior public servants it was an affront to their professionalism and integrity that would not be forgiven or forgotten. He had created an enemy within.

Third, one of Rudd's most glaring weaknesses was his inability to remain focused on the candle of seeing reforms through by dealing with a few significant reforms at a time before moving on. Moreover, his reluctance to empower colleagues to get on with the job was a recipe for created confusion; witness the problems with climate change and home insulation. Within months of Labor winning power, the Prime Minister was instead busy declaring war on everything and everybody: drugs, unemployment, doping in sport, bankers' salaries, whalers, climate change, inflation, water management, housing, free trade with China, the US alliance, cooperative federalism - all became 'priority issues'. Indeed, Rudd's attempts to crystallise these exhaustive and exhausting reform efforts 
into a stable governing code became increasingly over-intellectualised and desperate, culminating in his highly publicised essay in The Monthly in which he declared that 'the great neo-liberal experiment of the past 30 years has failed' and 'the challenge for social democrats today is to recast the role of the state'. That he would choose a 7000-word treatise in a literary magazine to win hearts and minds is indicative of his increasing detachment from the body politic.

\section{Political argument hegemony}

Certainly, Kevin Rudd has big rhetoric, but, looking closely at his policy initiatives, not yet a huge amount to back it up. Policy for policy, the government still resembles the one which was elected in 2007. The big ticket items have either failed to emerge (the national broadband network) or have been dramatically watered down or delayed such as the government's emissions trading scheme. (Berg 2010:1)

As Chris Berg (2010:1) argues, a further weakness in the statecraft of Kevin Rudd can be identified with his attempts to maintain political argument hegemony after his initial honeymoon period. This was reflected in the disparity between Rudd's rhetoric and his record of delivery. Although Berg overstates his caseas there have been no shortages of policy initiatives under Rudd - he is right to highlight the Prime Minister's inability to see the major policy items through to implementation. Rudd alienated the electorate and, most significantly, radicalised opposition within his own party as a consequence of seven policy debacles in a relatively short period.

- Emissions Trading Scheme: Rudd declared it the 'great moral issue of our time' and then deferred the legislation until 2012.

- Refugees: Rudd stopped the processing of applications from Sri Lankans and Afghans who arrived by boat.

- Home insulation: Rudd announced that 2.2 million Australian homes would get free ceiling insulation, revamped the scheme following deaths and fires, and then scrapped the program in April 2010.

- Building the Education Revolution: The primary school building program costing $\$ 16.2$ billion for 8000 schools was heavily criticised by an Australian National Audit Office (ANAO) report for a range of inefficiencies.

- Child care: Rudd quietly dumped his election pledge to build 260 childcare centres on school grounds to end 'the double drop-off' for parents.

- Northern Territory Intervention: Rudd continued a Howard policy that some claimed institutionalised apartheid in Australia.

- Mining Super Profits Tax: Rudd was unable to see the tax through in the face of mounting industry and media pressure and problems of internal party management. 


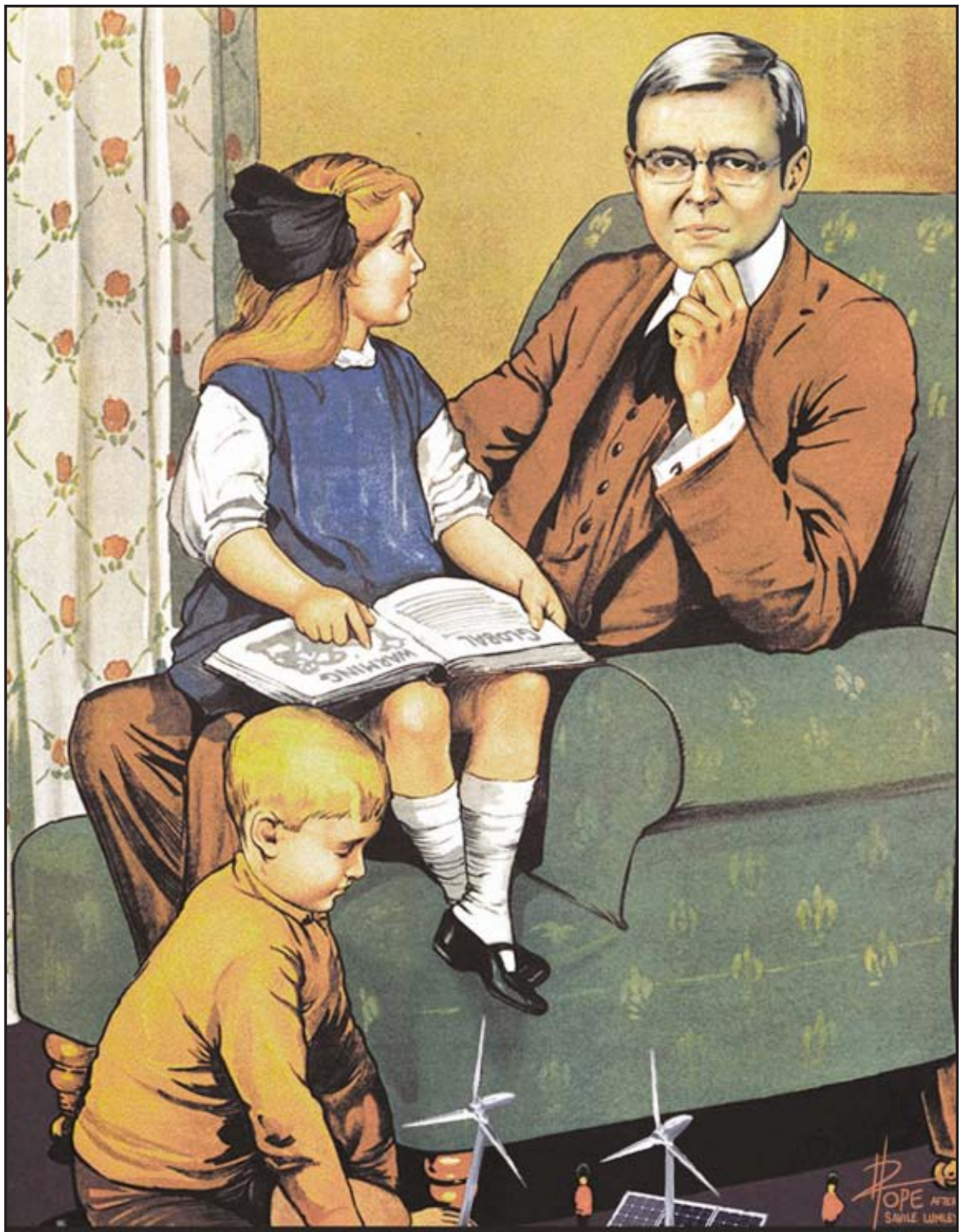

\section{Daddy, what did YoU do in the Great Moral Ghallenge of our Time?}

Source: David Pope, The Canberra Times, 28 April 2010. 
All of these debacles were characterised by a common error of judgment: Rudd raised expectations for progressive change and failed to deliver. Moreover, even in those areas where progress was made in the short term - for example, the apology to the 'Stolen Generations' or the emissions trading scheme-Rudd did not have the courage to see the policy through. For example, despite Rudd's apology on behalf of the Parliament to Australia's Stolen Generations for past government policies and practices of forcible removal, the Labor government is yet to deliver practical policy and funding initiatives to support reconciliation initiatives and other reparations for the Stolen Generations. Further, despite declaring the treatment of carbon emissions as the 'great moral issue of our time', he deferred the legislation until 2012 without a whisper of regret.

In sum, the failure to maintain political argument hegemony and thus the momentum of reform was a key failing of Rudd's statecraft. This required courageous leadership. As Tony Blair reflects in his autobiography:

The lesson is also instructive: if you think a change is right, go with it. The opposition is inevitable, but rarely is it unbeatable. There will be many silent supporters as well as the many vocal detractors. And leadership is all about the decisions that change. If you can't handle that, don't become a leader. And the lesson goes wider: it is about rising above the fray, learning how to speak above the din and clatter, and about always, always, keeping focused on the big picture. (Blair 2010:94)

\section{Party management}

We cannot be sure of course, but available evidence appears to suggest that most members of cabinet were ignorant that a coup against Rudd was afoot. Not only does this reveal the illegitimate nature of the process of leadership renewal in so far as it was forced through in the most brutal way by a handful of conspirators, it also shows that their-Victorian Lower House MP Bill Shorten, Victorian Senator David Feeney and NSW Senator and former NSW State Secretary Mark Arbib - judgment on the hiring and firing of a prime minister was sovereign. I will leave others to consider the constitutional implications of this development, but it has more in common with a feudal regime than a representative liberal democracy.

It is evident, however, that Rudd's landslide victory in 2007 created a 'Magic Kingdom' effect at the heart of Australian government in the sense that it lulled Rudd into a false sense of security and masked the fact that his relationship with the party caucus was built on continued electoral success. Christine Jackman traces Rudd's fall from the publication of 'Power Trip: The political journey of Kevin Rudd': 
Months earlier...Marr could scarcely have anticipated the political tinderbox into which he would eventually drop his crackling conclusion that the Australian prime minister was 'a politician with rage at his core'. But by midyear Rudd's remarkable personal approval ratings had collapsed, dragging down Labor's lead in the polls, and the mood in the caucus was febrile. Marr's rage thesis gave the mob, fearful for its political life, a rhetorical rallying point around which it could muster and finally canvass openly its angst-and worse-about its once untouchable leader. (Jackman 2010:1)

By the end of that month, Rudd would be gone.

\section{Parting shots: the sorcerer's apprentice}

In politics, what a leader does in achieving positive social and economic outcomes for the citizenry should be the basis on which their legacy is assessed rather than issues of personality. Unfortunately, this is rarely the case in practice. Perceptions are everything in politics. History will look more kindly on the Rudd legacy if the Gillard government is able to complete the reformation 'from age to youth, from fear to hope, from private to public' (Brett 2008:6), but it will fail to understand why the momentum for progressive change was lost so quickly after Rudd created so much political capital in his honeymoon period.

This cursory evaluation of the fall of the Rudd government has clearly demonstrated the value of the statecraft approach in exposing the ingredients of sustainable prime ministerial power anchored in the concept of resource dependency: the achievement of governing objectives; the establishment of a stable governing code; political argument hegemony; and party management. Kevin Rudd was not brought down by external events. Indeed, his government's handling of the global financial crisis (GFC), the signing of the Kyoto Protocol and the elevation of Australia to the G-20 are signature themes of his brief tenure as prime minister. Nor did he fall on the wrong side of the ideological battlelines in his party, for it remains a confection of strange bedfellows. Moreover, it would be ludicrous to claim that Tony Abbott's rejuvenation of the Coalition did anything more than make a dent in Rudd's fortunes as Prime Minister. So where does the preponderance of evidence lie? If Rudd as Minister for Foreign Affairs is not to repeat the mistakes of Rudd as Prime Minister, what lessons must he learn? First, he must not lose sight of the importance of his resource dependency on his party where he was always an outsider and will continue to be so. Second, he must not lose sight of his resource dependency on his cabinet colleagues and the advice and goodwill of his public servants and operate in a silo when progressive reform requires a whole-of-government approach and 
broad ownership. Third, he must not lose sight of his resource dependency on the Australian public, who welcomed him to power as if a prodigal son in 2007. Fourth, he must have the courage of his convictions and engage in courageous leadership. Rudd will always be known as the Prime Minister who failed to deliver on three of his big ideas: the carbon pollution reduction scheme, the emissions trading scheme and the mining super profits tax.

As the consequences of his inaction gained momentum, Kevin Rudd became the sorcerer's apprentice in Walt Disney's Fantasia, desperately trying to stem the tide of opposition. Rudd's Magic Kingdom became disconnected from party, politics and ultimately the core executive itself. It was born from electoral success and died due to fatal conceit.

Mark Evans is Director of the ANZSOG Institute for Governance at the University of Canberra.

\section{References}

Australian Broadcasting Corporation (ABC) 2008. 'Rudd tones down public servant blast', The World Today, ABC Online, 30 May.

Berg, C. 2010. 'Keeping up with Kevin: Kevin Rudd's testosterone technocracy', IPA Review, <www.ipa.org.au/publications/1661/keeping-up-with-kevinkevin-rudd \%27s-testosterone-technocracy $>$

Blair, T. 2010. The Journey, Random House, London.

Brett, J. 2008. 'The turning tide', in T. Jones (ed.), The Best Australian Political Writing, Melbourne University Press, Carlton, Vic., pp. 6-12.

Buller, J. 2000. National Statecraft and European Integration, Pinter, London.

Bulpitt, J. 1986a. 'The discipline of the new democracy: Mrs Thatcher's domestic statecraft', Political Studies, vol. 34, pp. 19-39.

Bulpitt, J. 1986b. 'Continuity, autonomy and peripheralisation: the anatomy of the centre's statecraft in England', in Z. Layton-Henry and P. Rich (eds), Race, Government and Politics in Britain, Macmillan, London.

Bulpitt, J. 1995. 'Historical politics: macro, in-time, governing regime analysis', in J. Lovenduski and J. Stanyer (eds), Contemporary Political Studies 1995. Volume Two, PSA, Exeter, UK, pp. 510-20. 
Crabb, A. 2010. Rise of the Ruddbot: Observations from the gallery, Black Inc., Melbourne.

Crossman, R. 1963. 'Introduction', in W. Bagehot, The English Constitution, Collins, London.

Dunleavy, P. and Rhodes, R. A. W. 1990. 'Core executive studies in Britain', Public Administration, vol. 68, no. 1, pp. 3-28.

Fraser, A. and Hannon, K. 2008. 'Now it's Rudd's war on the PS', The Canberra Times, 30 May.

Hall, S. and Jacques, M. 1983. The Politics of Thatcherism, Blackwell, Cambridge.

Hennessy, P. 1986. The Cabinet, Blackwell, Oxford.

Hennessy, P. 2000. The Prime Ministers, Penguin, London.

Jackman, C. 2010. 'Why we still need to talk about Kevin', The Australian, 4 August, <www.theaustralian.com.au/news/arts/why-we-still-need-to-talkabout-kevin/story-e6frg8nf-1225900075141>

Jones, T. (ed.) 2008. The Best Australian Political Writing, Melbourne University Press, Carlton, Vic.

Kelly, P. 2005. Rethinking Australian governance - the Howard legacy, Occasional Paper Series No. 4, Academy of the Social Sciences in Australia, Canberra.

Kelly, P. 2010a. The March of the Patriots, Melbourne University Press, Carlton, Vic.

Lewis, S. and Rehn, A. 2008. 'Kevin Rudd: working for me's a dog year', Daily Telegraph, 2 June.

McDonnell, J. 2008. 'Public service in revolt', The Australian, 2 June.

McLennan, D. and Cronin, D. 2010. 'Calculating an election win', The Canberra Times, 15 May.

Mann, S. 2008. 'The making of Kevin Rudd'. In T. Jones (ed.), The Best Australian Political Writing, Melbourne University Press, Carlton, Vic., pp. 13-25.

Marr, D. 2010a. 'Power Trip: The political journey of Kevin Rudd', Quarterly Essay, June, Black Inc., Melbourne.

Marr, D. 2010b. 'Marr discusses Rudd's "angry heart"', 7.30 Report, ABC TV, 7 June, <www.abc.net.au/7.30/content/2010/s2920783.htm> 
Megalogenis, G. 2008. 'The small picture men', in T. Jones (ed.), The Best Australian Political Writing, Melbourne University Press, Carlton, Vic., pp. 47-50.

Nethercote, J. 2010. 'A man of words, but little else', The Public Sector Informant, August.

Penberthy, D. 2009. 'Will the real Kevin Rudd please stand up', The Punch, 22 September.

Rhodes, R. A. W. 1995. 'From Prime Ministerial power to core executive', in R. A. W. Rhodes and P. Dunleavy (eds), Prime Minister, Cabinet and Core Executive, Macmillan, London.

Rhodes, R., Wanna, J. and Weller, P. 2009. Westminster Compared, Oxford University Press, Oxford.

Rose, R. 2001. The Prime Minister in a Shrinking World, Polity Press, Cambridge.

Smith, M. 1994. 'The core executive and the resignation of Mrs Thatcher', Public Administration, vol. 72, no. 3, pp. 341-63.

Trinca, H., Clegg, B., Dusevic, T., Elliott, G., Gluyas, R., Hepworth, A., Kerr, C., Korporaal, G., Megalogenis, G. and McKenna, M. 2010. 'The enemy within', The Weekend Australian, 3-4 July.

Weller, P. 1992. Menzies to Keating: The development of the Australian prime ministership, Hurst, London.

Weller, P. 2007. Cabinet Government in Australia, 1901-2006, UNSW Press, Sydney. 